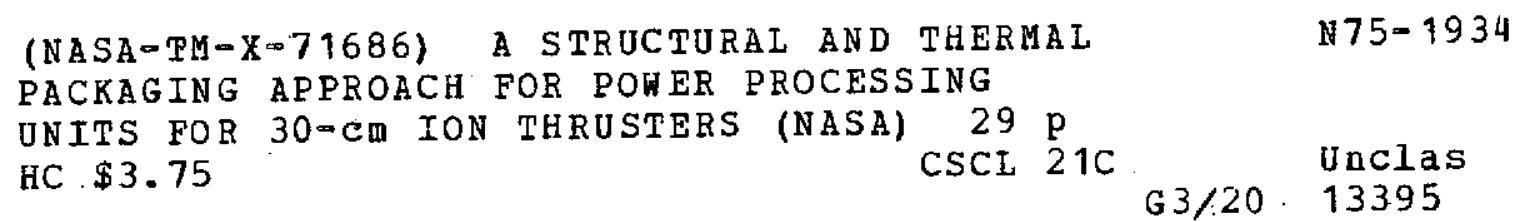

\title{
A STRUCTURAL AND THERMAL PACKAGING APPROACH FOR POWER PROCESSING UNITS FOR 30-CM ION THRUSTERS
}

by J. E. Maloy and G. R. Sharp

Lewis Research Center

Cleveland, Ohio 44135

TECHNICAL PAPER to be presented at

Eleventh Electric Propulsion Conference sponsored by American Institute of Aeronautics and Astronautics New Orleans, Louisiana, March 19-21, 1975

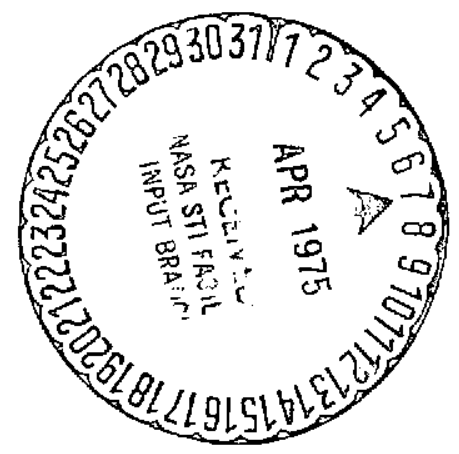


A STRUCTURAL AND THERMAL. PACKAGING APPROACH FOR POWER

PROCESSING UNITS FOR 30-CM ION THRUSTERS

J. E. Maloy and G, R. Sharp

Lewis Research Center

\begin{abstract}
Solar Electric Propulsion (SEP) is currently being studied for possible use in a number of near Earth and planetary missions. The thruster subsystem for these missions would consist of 30 centimeter ion thrusters with Power Processor Units (PPU) clustered in assemblies of from two to ten units. A preliminary design study of the electronic packaging of the PPU has been completed at Lewis Research Center of NASA. This study eva1uates designs meeting the competing requirements of 1 ow system weight and overall mission flexibility. These requirements are evaluated regarding structural and thermal design, electrical efficiency, and integration of the electrical circuits into a functional PPU layout.
\end{abstract}

\title{
INTRODUCTION
}

Research and development work has been carried on since the late fifties on components for solar electric propulsion (SEP). One of the most critical of these components is the power processor unit (PPU). It is used to convert raw d.c. power to the various voltages and currents required by the ion thruster.

Power processors were successfully developed and flown on both the SERT I (1964) and SERT II (1970) spacecraft. The SERT I spacecraft of reference 1 successfully demonstrated that ion thrusters could operate and produce thrust in space. The SERT II spacecraft described in reference 2 was launched to (a) prove the reliability and endurance of an ion thruster, and (b) ascertain ion thruster operating characteristics in the space environment.

The thruster power processor circuitry for the SERT I mission was packaged in two pressurized boxes. For SERT II, the power processor was packaged in a single electronics box incorporating command, telemetry, and power circuitry. The SERT II power processor transformers incorporated open construction.

The Lewis Research Center has contracted power processing circuit development efforts for the SEP 30 centimeter ion thruster at both TRW (ref. 3) and Hughes Aircraft $\mathrm{Co}$. (HAC) (ref. 4). Both power processor versions use open construction similar to SERT II and are packaged in a flat plate design where the high heat dissipation components are allotted 
areas on a radiator plate according to their dissipation. Thus heat is conducted from the components into the radiator plate and then radiated directly to space.

JPL has performed a SEP PPU packaging study resulting in a dual shear plate packaging design described in reference 5. Thermal contro1 for this concept is by direct radiation through louvers. The electrical circuits are mounted to channel or I-section cross-beams which span the width of the rectangular radiator plate. A second rectangular plate on the back of the PPU structurally stabilizes the cross-beams. Spacecraft shear loads are transferred to the surrounding spacecraft frame through both the radiator and the back shear plate.

The NASA Lewis Research Center has recently performed in-house PPU packaging studies for the 30-centimeter mercury ion thruster SEP missions. These studies build on the comprehensive work done by JPL, TRW, HAC, and others. This paper presents the results of a parametric analysis of various PPU conceptual designs which meet the mechanical, electrical, and thermal requirements imposed by the proposed SEP missions. Studies were conducted at the Lewis Research Center to determine the trades associated with thermal control achieved by (a) a combination of direct radiation through louvers and conduction to a remote radiator by variable conductance heat pipes (VCHP), (b) direct radiation through louvers, or (c) an all VCHP system. Weights were calculated as a function of thermal contro1 concept, thermal environment, electronic component junction temperature, electrical efficiency, and radiator efficiency. The detailed thermal analysis reported herein was based on CINDA (ref. 6) programs. Structural analyses were based in part on NASTRAN (ref. 7) programs.

\section{PPU PACKAGING REQUIREMENTS}

The PPU packaging studies of this paper were constrained by a number of specific thermal, mechanical, and electrical requirements. These requirements were in addition to the obvious functional requirements.

Thermal

The SEP mission and PPU thermal environmental requirements are listed in table $\mathrm{I}$. The PPU typically rejects heat from outboard facing surfaces as shown in figure 1. Therefore, the PPU thermal design must be compatible with the thermal influence of the solar arrays such as those proposed in reference 12 .

Typica1 electrical component temperature limits to assure high reliability are $-15^{\circ}$ to $85^{\circ} \mathrm{C}$ (operating) and $-40^{\circ}$ to $100^{\circ} \mathrm{C}$ (nonoperating). For optimum interchangeability between different SEP spacecraft, the basic PPU package thermal design must be thermally independent from other spacecraft components. 
Mechanica1

For structural weight savings, the power processor package should be constructed so that the spacecraft and PPU launch acceleration loads are transmitted through the PPU structure. A shear load requirement of 11.25 kilograms per centimeter (63 lb/in.) along each side of the PPU was assumed for this study based on reference 5 .

The maximum thrust and lateral quasi-static (1aunch vehicle acceleration plus launch vehicle low frequency sine vibration) is given in table II for candidate SEP launch vehicles. The unamplified spacecraft qualification sine and random vibration environments for the various launch vehicles are given in figures 2 and 3 , respectively. Component vibration qualification levels for typical SEP spacecraft are also presented.

The cross-beams should be designed for beam resonances and web resonances above 200 Hertz to avoid vibration coupling with other major spacecraft systems.

\section{Electrical}

The primary electrical requirement of the PPU is to efficiently convert electric power into voltages and currents required by the ion thruster. Secondary requirements are (a) modularization of the circuitry to facilitate circuit repair and replacement, and (b) separation of high voltage and high amperage power output from the low voltage circuitry in order to limit electro-magnetic interference (EMI) in the sensitive circuits.

A functional block diagram for bridge-rectifier transistorized PPU circuits is shown in figure 4. The block diagram for the Series Resonant SCR PPU circuitry is shown in figure 5. These block diagrams are used as starting points for the modularization of the circuitry. Modularization is then completed in conjunction with the actual packaging design layouts.

\section{OPTIONS AND DESIGN APPROACH}

Three different PPU packaging design concepts were studied. Total PPU package weight (including thermal control system weight) was estimated for each design. The three conceptual design systems were (a) an all louver system as shown in figure 6, (b) a variable conductance heat pipe and louver system (both working concurrently) as shown in figure 7 , and (c) an all variable conductance heat pipe system (VCHPS) as shown in figure 8 . 


\section{A11 Louver Configuration}

The al1 louver system resembles the JPL dual shear plate design described in reference 5. In this design, electrical component thermal dissipations are conducted to the module outer flange and then to the outer shear plate. High heat dissipation components are located on the outboard (radiator facing) flanges of the submodule cross-beams to provide for a more direct thermal path to the radiator. Waste heat is radiated from one side of the radiator through thermostatically controlled louver blades to space.

When direct radiation through louvers is used for thermal control, a temperature gradient of $10^{\circ} \mathrm{C}$ or less must be maintained over the radiator surface in order to prevent the components of the individual modules from exceeding the temperature limits.

The functional block diagram for the bridge-rectifier transistorized PPU circuits has been converted into circuit modules. The modules and their arrangement for the all louver system are shown in figure 9. This arrangement incorporates uniform heat load distribution and minimizes temperature gradients. However, the arrangement is not electrically ideal in that it was not possible to separate the high and low voltage circuits and still meet the thermal gradient requirements.

\section{VCHPS-Louver Configuration}

In the VCHPS-louver configuration shown in figure 7 the electrical components are also mounted on individual $\mathrm{z}$-section cross-beam modules. Physically large components and high thermal dissipation electrical components are mounted directly on the radiating (outboard or space facing) flanges of the $\mathrm{Z}$-section cross-beams. The radiating flanges are then bolted directly to the evaporator saddles of the VCHPS (an outer shear plate is not requixed). Components with the largest thermal dissipations are mounted close to the evaporator saddles as shown in figure 10 . Components with lower thermal dissipations and printed circuit cards are mounted to the cross-beam webs. The single sided louvered radiating area of the PPU proper was assumed to be 61 by 71.1 centimeters ( 24 by 28 in.). Two heat pipes are attached to each VCHPS saddle, with the second pipe being redundant. Waste heat in excess of the capacity of the louvered radiating area is conducted by the heat pipes to a remote therma11y isolated $40 \mathrm{mil}$ aluminum single sided radiator.

Magnesium alloy ZK60AT5 was chosen for the Z-section cross beams because of its high thermal conductivity to weight ratio. AZ31BH24 magnesium alloy was chosen for the back shear plate for its 1ight weight since a high thermal conductivity was not necessary.

The same bridge-rectifier transistorized circuit modules as were used for the all louver system are used for the VCHPS-louver configuration. However, the module arrangement as shown in figure 11 is electri- 
cally ideal with complete separation of the high voltage and high amperage circuits from the input power, control and telemetry circuits. This module arrangement was made possible only by using heat pipes for thermal control since the $10^{\circ} \mathrm{C}$ thermal gradient requirement of the all louver system no longer applied.

Although the bridge-rectifier transistorized circuitry was used to illustrate the packaging approach, the same procedure is valid for the series-resonant SCR PPU circuitry.

\section{All VCHPS Configuration}

For the all VCHPS configuration as shown in figure 8 , the electronic components are mounted on individual $\mathrm{Z}$-section cross-beam modules and arranged identical to the VCHPS-louver configuration. However, the total heat load is dissipated by the single sided heat pipe radiator. Therefore, a larger total radiator area is needed than for the VCHPS-louver configuration.

\section{PARAMETRIC STUDY RESULTS}

A description of the methodology and findings of a solar electric propulsion power processor parametric design study are presented below.

\section{Methods}

In performing the parametric analysis certain assumptions were made based on the wide range of expected PPU environmental conditions. A list of the general thermal assumptions is shown in table III. The solar array temperature variation corresponds to (a) SEP mission sun-to-spacecraft distances ranging from 0.7 to $3.5 \mathrm{~A} . \mathrm{U}$., as discussed in reference 8 , and (b) tilting of the array to limit its maximum temperature to $140^{\circ} \mathrm{C}$. Radiator thickness and weight were allowed to increase in order to meet the al1-1ouver requirement for a $10^{\circ} \mathrm{C}$ temperature gradient across the radiator-surface. The weight assumptions for the VCHPS are based on the Communications Technology Satellite VCHPS technology described in reference 13. A schematic representation of the major heat paths accounted for in the analysis is shown in figure 12. In the analyses, VCHP radiator fin efficiency was defined as

$$
\text { fin effictency }=\frac{\text { calculated area at constant temperature }}{\text { actual required area }}
$$

where fin efficiency accounts for both temperature drop from the condenser saddle to the radiating fin, and temperature gradients along the fin. A typical electronic component junction temperature rise above the VCHP saddle or front radiator plate (al1 louver configuration) was $24^{\circ} \mathrm{C}$. This was based on a calculated thermal resistance of $2^{\circ} \mathrm{C}$ per watt be- 
tween a typical 12 watt dissipation bridge rectifier case junction and the VCHP saddle.

\section{Results}

The results of the parametric studies are included in tables IV(a) to (c) and figures 13 to 20, where curves compare the PPU system weight as a function of (a) thermal control concept, (b) component junction temperature or radiator surface temperature, (c) solar array temperature, (d) radiator emittance, (e) total heat load, and (f) VCHPS radiator fin efficiency. These weights are for preliminary designs of the PPU package, not for final or flight designs.

Figures 13 through 15 compare the PPU system weights as a function of solar array temperature, component junction temperature, and electrical heat load. The curves show that (a) for any one set of conditions, an all louver PPU system is always heavier than the VCHPS 1 louver system, (b) for any one set of conditions, the VCHPS-louver PPU concept system weight is less sensitive to both component junction temperature change, and solar array temperature change than the all louver PPU concept system weight, and (c) the system weight for an all VCHPS concept and a VCHPSlouver concept (where the louver covered area is 61 by $71.1 \mathrm{~cm}$ ) are nearly the same when single sided radiators are used for both designs. Weight saved by removal of the louvers is nullified by weight of a larger VCHPS radiator and its supporting structure. However, for a louver radiator area larger than 61 by 71.1 centimeters, an al1 VCHPS system would be lighter than a VCHPS-louver system. This is primarily due to the front radiating flange thickness increasing to maintain a radiator surface temperature gradient of $10^{\circ} \mathrm{C}$.

Effect of radiator view factor to space. - From figures 16, 13, and 17 showing the effect on the system weight of radiator view factors to space of $0.775,0.83$, and 0.94 , respectively, it should be noted that the VCHPS-louver system weight is less sensitive to change in radiator view factor to space than the all louver PPU system weight.

Effect of louver emittance. - A comparison of figures 13 and 18 shows that increasing the louver emittance from 0.65 to 0.70 reduces both system weight and weight sensitivity.

Effect of solar array temperature. - Figure 19 shows the system weight as a function of component function temperature for various solar array temperatures. The VCHPS-louver PPU system weight is far less sensitive to solar array temperature than the all louver PPU weight.

Effect of PPU electrical efficiency. - Figure 20 is a comparison of system weights as a function of PPU electrical efficiency at several component temperatures for an input power of 3000 watts and for a solar ar ray temperature of $140^{\circ} \mathrm{C}$. The VCHPS-louver PPU system weight is far less sensitive to electrical efficiency changes than the all louver system weight。 


\section{CONCLUDING REMARKS}

The parametric study in the present paper shows that a PPU using a VCHPS-louver thermal control system would be less sensitive than a PPU using an all louver thermal control system to (a) environmental conditions, (b) component junction temperature requirements, and (c) electrical efficiency. The present study also shows that a light weight, compact PPU could be achieved by using a VCHPS-louver thermal control system. This VCHPS-louver construction permits (a) electrical circuits to be arranged to meet desirable electrical requirements, and (b) a standard PPU configuration with test and qualification benefits, as wel1 as a reduction in program costs for flight spares.

The results presented in this paper are preliminary. Further refinements in circuits, circuit layouts, component selection and component dissipation are anticipated. Future work should include (a) a more detailed computer analysis of both the structural and thermal designs, including trades between double and single sided VCHPS radiators, (b) building a prototype PPU using flight type electronics, louvers, and VCHPS, and

(c) performing mechanical electrical and thermal qualification tests.

\section{REFERENCES}

1. Cybulski, R. J., Shellhammer, D. M., Lovell, R. R., Domino, E. J., and Kotnik, J. J., "Results from SERT I Ion Rocket Flight Test," TN D-2718, 1965, NASA.

2. Goldman, R. G., Gurski, G. J., and Hawersaat, W. H.. "Description of SERT II Spacecraft and Mission," NASA TM X-2087, 1970.

3. Biess, J. L., Inouye, L. V., and Shank, J. H.s "High Vo1tage Series Resonant Inverter Ion Engine Supply," 1974, TRW Systems, Inc., Redondo Beach, Ca11f.

4. Sung, S.; and Herron, B. G.: Development of a 30-Centimeter Ion Thruster-Thermal-Vacuum Power Processor. AIAA Paper 75- , New Orleans, Louisiana, 1975.

5. "Solar Electric Propulsion (SEP) Dual Shear Plate Packaging Design," Doc. No. 701-204, 1974, Jet Propulsion Lab., Pasadena, Calif.

6. Gaski, J. D., and Lewis, D. D., "IBM-7094-1105 Computer Program C09945, Chrysler Improved Numerical Differencing Analyzer," TN-AP-66-15, 1966, Chrysler Corp.; also CR-89100, 1966, NASA.

7. "NASTRAN: Users' Experiences," TM X-2378, 1971, NASA.

8. Duxbury, J. H., "A Solar-Electric Spacecraft for the Encke Show Flyby Mission," AIAA Paper 73-1126, Lake Tahoe, Nev., 1973.

9. Gilbert, J., and Guttman, C. H., "Evolution of the SEP Stage/SEPS/ Concept," AIAA Paper 73,1122, Lake Tahoe, Nev., 1973. 
10. "Concept Definition and Systems Analysis Study for a Solar Electric Propulsion Stage。" SD-74-SA-0176, Vols. 1 thru 4, Rockwell Internationa1, Douney, Calif.

11. "Concept Definition and System Analysis Study for a Solar Electric Propulsion Stage," D180-18553-1, Vols. 1 thru 5, 1975, Boeing Aerospace Co., Seattle, Wash.

12. "Solar Array Technology Evaluation Program for SEPS (Solar Electrical Propulsion on Stage)," LMSC-D384250, Sept. 1974, Lockheed Missiles and Space Co.; also CR-120483, 1974, NASA。

13. Marcus, B. D., and Sherwood, D. J., "TRW: TEP Variable Conductance Heat Pipe System Preliminary Design Review Package," 1973, TRW Systems, Inc。, Redondo Beach, Calif。 
TABLE I. - REPRESENTATIVE SEP MISSIONS AND PPU THERMAL REQUIREMENTS

\begin{tabular}{|c|c|c|c|c|}
\hline Mission & $\begin{array}{c}\text { PPU } \\
\text { therma } 1 \\
\text { dissipation, } \\
\text { W }\end{array}$ & $\begin{array}{c}\text { Distance } \\
\text { from } \\
\text { Sun, } \\
\text { A.U. }\end{array}$ & $\begin{array}{l}\text { Solar } \\
\text { array } \\
\text { temperature, } \\
\text { o }_{\mathrm{C}} \\
\text { (b) }\end{array}$ & $\begin{array}{c}\text { Required } \\
\text { component } \\
\text { junction } \\
\text { temperature, } \\
{ }^{\circ} \mathrm{C}\end{array}$ \\
\hline $\begin{array}{l}\text { Encke }{ }^{(8)} \\
\text { Comet rendezvous }\end{array}$ & $\begin{array}{r}a_{387} \\
0\end{array}$ & $\begin{array}{l}0.7 \\
3.5\end{array}$ & $\begin{array}{r}140 \\
c_{-}-112\end{array}$ & $\begin{array}{r}85 \\
-15\end{array}$ \\
\hline $\begin{array}{l}\text { Earth }(9-11) \text { or- } \\
\text { bital } \\
14824 \mathrm{~m} \\
(8000 \mathrm{n} \mathrm{mi}) \text { al- } \\
\text { titude or greater }\end{array}$ & $\begin{array}{r}a_{387} \\
0\end{array}$ & $\begin{array}{l}1 \\
1\end{array}$ & $\begin{array}{r}50 \\
-220\end{array}$ & $\begin{array}{r}85 \\
-15\end{array}$ \\
\hline
\end{tabular}

a Based on a 87 percent efficient PPU.

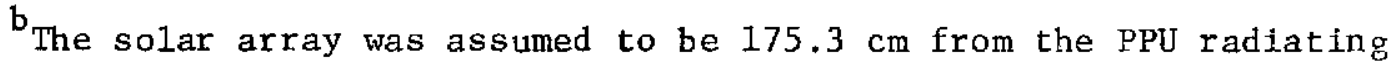
surfaces. The assumed view factor from the PPU to the solar array is 0.17 .

$\mathrm{C}_{\text {At }} 2.5 \mathrm{~A} . \mathrm{U} . \approx-100^{\circ} \mathrm{C}$. 
TABLE II. - MAXIMUM THRUST AND LATERAL QUASISTATIC

LAUNCH VEHICLE ACCELERATIONS

\begin{tabular}{|l|c|l|l|}
\hline Launch Vehicle & $\begin{array}{c}\text { Thrust } \\
\text { acceleration, } \\
\text { g's }\end{array}$ & \multicolumn{2}{|c|}{$\begin{array}{c}\text { Lateral } \\
\text { acceleration, } \\
\text { g's }\end{array}$} \\
\hline De1ta (2-stage) & $+2.9 /-1.0$ & 2.0 applied simul taneous1y with thrust \\
& 12.0 & .65 & \\
Atlas Centaur & 7.2 & 1.0 & \\
Titan Centaur & 5.6 & 1.3 & \\
Shuttle & 1.0 & 2.8 & \\
& -0.8 & 2.2 & .75 \\
SEP flight & -3.3 & 2.8 & \\
requirements & 12.0 & & \\
SEP qualification & 18.0 & 4.2 & \\
requirements & & & \\
\hline
\end{tabular}


TABLE III. - GENERAL THERMAL ASSUMPTIONS

\begin{tabular}{|c|c|c|c|}
\hline & \multicolumn{3}{|c|}{ Configuration } \\
\hline & All louver & VCHP/louver & VCHPS \\
\hline $\begin{array}{l}\text { Solar array temperature } \\
\text { Solar array emittance } \\
\text { Radiator view factor } \\
\text { to space } \\
\text { Radiator view to } \\
\text { solar array } \\
\text { Louver radiator emit- } \\
\text { tance } \\
\text { Louver absorptance } \\
\text { VCHP fin emittance } \\
\text { VCHP fin absorptance } \\
\text { Thermally isolated } \\
\text { from other PPU's } \\
\text { Temperature gradient }\end{array}$ & $\begin{array}{l}0.65(0.70) \\
0.2 \text { to } 0.32 \\
--- \\
\text { Yes } \\
10^{\circ} \text { C max } \\
\text { vertically } \\
\text { along the } \\
\text { front radi- } \\
\text { ator } \\
3^{0} \text { C trans- } \\
\text { verse } \\
\text { across ra- } \\
\text { diator }\end{array}$ & $\begin{array}{c}\text { [Range: } \\
0.83 \text { [Range } \\
0.17 \text { [Range } \\
0.65(0.70) \\
0.2 \text { to } 0.32 \\
0.88 \\
0.2 \text { to } 0.32 \\
\text { Yes }\end{array}$ & $\begin{array}{c}50^{\circ} \mathrm{C} \text { at } 1 \mathrm{~A} . \mathrm{U} \\
\left.100^{\circ} \text { to } 140^{\circ} \mathrm{C}\right] \\
0.775 \text { to } 0.94] \\
0.225 \text { to } 0.06] \\
--- \\
0.88 \\
0.2 \text { to } 0.32 \\
\text { Yes } \\
1^{\circ} \mathrm{C} \text { from VCHP } \\
\text { evaporator to } \\
\text { condenser }\end{array}$ \\
\hline
\end{tabular}


TABLE IV

(a) All louver system weights $(\mathrm{kg} / 1 \mathrm{~b})$

\begin{tabular}{|c|c|c|c|c|c|c|}
\hline \multirow[t]{2}{*}{ Elements } & \multicolumn{6}{|c|}{ Radiator area, $\mathrm{m}^{2} / \mathrm{ft} \mathrm{t}^{2}$} \\
\hline & $0.650 / 7$ & $0.929 / 10$ & $1.208 / 13$ & $1.486 / 16$ & $1.765 / 19$ & $2.044 / 22$ \\
\hline $\begin{array}{l}\text { 1. Electrical com- } \\
\text { ponents }\end{array}$ & $13.89 / 30.61$ & $13.89 / 30.61$ & $13.89 / 30.61$ & $13.89 / 30.61$ & $13.89 / 30.61$ & $13.89 / 30.61$ \\
\hline 2. Harness & $1.16 / 2.55$ & $1.36 / 3.00$ & $1.56 / 3.45$ & $1.77 / 3.90$ & $1.97 / 4.35$ & $2.18 / 4.80$ \\
\hline 3. Connectors & $1.13 / 2.50$ & $1.13 / 2.50$ & $1.13 / 2.50$ & $1.13 / 2.50$ & $1.13 / 2.50$ & $1.13 / 2.50$ \\
\hline $\begin{array}{l}\text { Total electrical } \\
\text { component weight }\end{array}$ & $16.18 / 35.66$ & $16.35 / 36.11$ & $16.58 / 36.56$ & $16.79 / 37.01$ & $16.99 / 37.46$ & $17.20 / 37.91$ \\
\hline 4. Hardware & $1.76 / 3.88$ & $1.76 / 3.88$ & $1.76 / 3.88$ & $1.76 / 3.88$ & $1.76 / 3.88$ & $1.76 / 3.88$ \\
\hline 5. Cross beams & $2.20 / 4.85$ & $2.20 / 4.85$ & $2.20 / 4.85$ & $2.20 / 4.85$ & $2.20 / 4.85$ & $2.20 / 4.85$ \\
\hline Total module weight & $20.14 / 44.39$ & $20.34 / 44.84$ & $20.54 / 45.29$ & $20.75 / 45.74$ & $20.95 / 46.19$ & $21.16 / 46.64$ \\
\hline 6. Back shear plate & $1.17 / 2.58$ & $1.67 / 3.68$ & $2.17 / 4.78$ & $2.67 / 5.88$ & $3.17 / 6.98$ & $3.67 / 8.10$ \\
\hline Total & $21.31 / 46.97$ & $22.01 / 48.52$ & $22.71 / 50.07$ & $23.42 / 51.62$ & $24.12 / 53.17$ & $24.83 / 54.74$ \\
\hline 7. Radiator plate & $2.31 / 5.10$ & $.4 .67 / 10.30$ & $7.89 / 17.40$ & $11.97 / 26.40$ & $16.87 / 37.20$ & $22.63 / 49.90$ \\
\hline Total & $23.62 / 52.07$ & $26.68 / 58.82$ & $30.60 / 67.47$ & $35.39 / 78.02$ & $40.99 / 90.37$ & $47.86 / 104.64$ \\
\hline $\begin{array}{l}\text { 8. Louver and } \\
\text { louver support } \\
\text { weight }\end{array}$ & $3.43 / 7.56$ & $4.90 / 10.80$ & $6.37 / 14.04$ & $7.84 / 17.28$ & $9.31 / 20.52$ & $10.78 / 23.76$ \\
\hline Tota1 & $27.05 / 59.63$ & $31.58 / 69.62$ & $36.97 / 81.51$ & $43.23 / 95.30$ & $50.30 / 110.89$ & $58.24 / 128.40$ \\
\hline
\end{tabular}


TABLE IV. - Continued.

\begin{tabular}{|c|c|c|c|c|c|c|c|}
\hline Elements & \multicolumn{7}{|c|}{ Heat pipe radiator area, $\mathrm{m}^{2} / \mathrm{ft}^{2}$} \\
\hline & $0.279 / 3$ & $0.557 / 6$ & $0.836 / 9$ & $1.115 / 12$ & $1.394 / 15$ & $1.672 / 18$ & $1.951 / 21$ \\
\hline $\begin{array}{l}\text { 1. Electrical com- } \\
\text { ponents }\end{array}$ & $13.88 / 30.61$ & $13.88 / 30.61$ & $13.88 / 30.61$ & $13.88 / 30.61$ & $13.88 / 30.61$ & $13.88 / 30.61$ & $13.88 / 30.61$ \\
\hline 2. Harness & $0.68 / 1.50$ & $0.68 / 1.50$ & $0.68 / 1.50$ & $0.68 / 1.50$ & $0.68 / 1.50$ & $0.68 / 1.50$ & $0.68 / 1.50$ \\
\hline 3. Connectors & $1.13 / 2.50$ & $1.13 / 2.50$ & $1.13 / 2.50$ & $1.13 / 2.50$ & $1.13 / 2.50$ & $1.13 / 2.50$ & $1.13 / 2.50$ \\
\hline $\begin{array}{l}\text { Total electrical com- } \\
\text { ponent weight }\end{array}$ & $15.69 / 34.61$ & $15.69 / 34.61$ & $15.69 / 34.61$ & $15.69 / 34.61$ & $15.69 / 34.61$ & $15.69 / 34.61$ & $15.69 / 34.61$ \\
\hline 4. Hardware & $1.34 / 2.96$ & $1.34 / 2.96$ & $1.34 / 2.96$ & $1.34 / 2.96$ & $1.34 / 2.96$ & $1.34 / 2.96$ & $1.34 / 2.96$ \\
\hline 5. Cross beams & $2.37 / 5.23$ & $2.37 / 5.23$ & $2.37 / 5.23$ & $2.37 / 5.23$ & $2.37 / 5.23$ & $2.37 / 5.23$ & $2.37 / 5.23$ \\
\hline 6. Back shear plate & $0.43 / 0.94$ & $0.43 / 0.94$ & $0.43 / 0.94$ & $0.43 / 0.94$ & $0.43 / 0.94$ & $0.43 / 0.94$ & $0.43 / 0.94$ \\
\hline Total PPU & $19.83 / 43.74$ & $19.83 / 43.74$ & $19.83 / 43.74$ & $19.83 / 43.74$ & $19.83 / 43.74$ & $19.83 / 43.74$ & $19.83 / 43.74$ \\
\hline $\begin{array}{l}\text { 7. Louver and louver } \\
\text { support structure } \\
1.081 \mathrm{~b} / \mathrm{ft}^{2} \\
+0.45=5.05 \\
+0.45=5.50\end{array}$ & $2.49 / 5.50$ & $2.49 / 5.50$ & $2.49 / 5.50$ & $2.49 / 5.50$ & $2.49 / 5.50$ & $2.49 / 5.50$ & $2.49 / 5.50$ \\
\hline Total & $22.32 / 49.24$ & $22.32 / 49.24$ & $22.32 / 49.24$ & $22.32 / 49.24$ & $22.32 / 49.24$ & $22.32 / 49.24$ & $22.32 / 49.24$ \\
\hline $\begin{array}{l}\text { 8. Evap. heat pipes } \\
\text { and saddles } \\
(3+3)(0.52)(26) \\
(0.1)+1.04 \\
=1.85\end{array}$ & $0.84 / 1.85$ & $0.84 / 1.85$ & $0.84 / 1.85$ & $0.84 / 1.85$ & $0.84 / 1.85$ & $0.84 / 1.85$ & $0.84 / 1.85$ \\
\hline $\begin{array}{l}\text { 9. Heat pipe gas } \\
\text { reservoirs }\end{array}$ & $0.80 / 1.76$ & $0.80 / 1.76$ & $0.80 / 1.76$ & $0.80 / 1.76$ & $0.80 / 1.76$ & $0.80 / 1.76$ & $0.80 / 1.76$ \\
\hline $\begin{array}{l}\text { 10. Condenser heat } \\
\text { pipes and saddles }\end{array}$ & $0.78 / 1.73$ & $1.57 / 3.46$ & $2.35 / 5.18$ & $3.13 / 6.91$ & $3.92 / 8.64$ & $4.70 / 10.37$ & $5.49 / 12.10$ \\
\hline $\begin{array}{l}\text { 11. Heat pipe radi- } \\
\text { ator }\end{array}$ & $0.77 / 1.69$ & $1.54 / 3.39$ & $2.30 / 5.08$ & $3.07 / 6.77$ & $3.84 / 8.47$ & $4.61 / 10.16$ & $5.38 / 11.85$ \\
\hline Total & $25.51 / 56.27$ & $28.07 / 59.69$ & $28.61 / 63.11$ & $30.17 / 66.54$ & $31.72 / 69.96$ & $33.27 / 73.38$ & $34.83 / 76.80$ \\
\hline
\end{tabular}


TABLE IV, - Concluded.

\begin{tabular}{|c|c|c|c|c|c|c|c|c|c|}
\hline \multirow[t]{2}{*}{ Elements } & \multicolumn{9}{|c|}{ VCHP $f 1 n$ area, $\mathrm{m}^{2} / \mathrm{ft}^{2}$} \\
\hline & $0.279 / 3$ & $0.557 / 6$ & $0.836 / 9$ & $1.115 / 12$ & $1.394 / 15$ & $1.672 / 18$ & $1.951 / 21$ & $2.230 / 24$ & $2.508 / 27$ \\
\hline 1. Electrical components & $13.89 / 30.61$ & $13.89 / 30.61$ & $13.89 / 30.61$ & $13.89 / 30.61$ & $13.89 / 30.61$ & $13.89 / 30.61$ & $13.89 / 30.61$ & $13.89 / 30.61$ & $13.89 / 30.61$ \\
\hline 2. Barness & $0.68 / 1.50$ & $0.68 / 1.50$ & $0.68 / 1.50$ & $0.68 / 1.50$ & $0.68 / 1.50$ & $0.68 / 1.50$ & $0.58 / 1.50$ & $0.68 / 1.50$ & $0.68 / 1.50$ \\
\hline 3. Connectors & $1.13 / 2.50$ & $1.13 / 2.50$ & $1.13 / 2.50$ & $1.13 / 2.50$ & $1,13 / 2.50$ & $1.13 / 2.50$ & $1.13 / 2.50$ & $1.13 / 2.50$ & $1.13 / 2.50$ \\
\hline Tota1 & $15.70 / 34.61$ & $15.70 / 34.61$ & $15.70 / 34.61$ & $15.70 / 34.61$ & $15.70 / 34.61$ & $15,70 / 34,61$ & $15.70 / 34.61$ & $15.70 / 34.61$ & $15.70 / 34.61$ \\
\hline 4. Har dware & $1.34 / 2.96$ & $1.34 / 2.96$ & $1.34 / 2.96$ & $1.34 / 2.96$ & $1.34 / 2.96$ & $1.34 / 2.96$ & $1.34 / 2.96$ & $1.34 / 2.96$ & $1.34 / 2.96$ \\
\hline 5. Cross beams & $2.37 / 5.23$ & $2.37 / 5.23$ & $2.37 / 5,23$ & $2.37 / 5.23$ & $2.37 / 5.23$ & $2.37 / 5.23$ & $2.37 / 5.23$ & $2.37 / 5,23$ & $2.37 / 5.23$ \\
\hline 6. Back shear plate & $0.43 / 0.94$ & $0.43 / 0.94$ & $0.43 / 0.94$ & $0.43 / 0.94$ & $0.43 / 0.94$ & $0.43 / 0.94$ & $0.43 / 0.94$ & $0.43 / 0.94$ & $0.43 / 0.94$ \\
\hline Total PPU & $19.84 / 43.74$ & $19.84 / 43.74$ & $19.84 / 43.74$ & $19.84 / 43.74$ & $19.84 / 43.74$ & $19.84 / 43.74$ & $19.84 / 43.74$ & $19.84 / 43.74$ & $19.84 / 43.74$ \\
\hline $\begin{array}{l}\text { 7. Fin support struc- } \\
\text { tures (4) }\end{array}$ & $0.18 / 0.40$ & $0.18 / 0.40$ & $0.18 / 0.40$ & $0.18 / 0.40$ & $0.18 / 0.40$ & $0.18 / 0.40$ & $0.18 / 0.40$ & $0.18 / 0.40$ & $0.18 / 0.40$ \\
\hline Total & $20.02 / 44.14$ & $20.02 / 44.14$ & $20.02 / 44.14$ & $20.02 / 44.14$ & $20.02 / 44.14$ & $20.02 / 44.14$ & $20.02 / 44.14$ & $20.02 / 44.14$ & $20.02 / 44.14$ \\
\hline $\begin{array}{l}\text { 8. Evaporation VCHP } \\
\text { and saddles }\end{array}$ & $0.84 / 1.85$ & $0.84 / 1.85$ & $0.84 / 1.85$ & $0.84 / 1.85$ & $0.84 / 1.85$ & $0.84 / 1.85$ & $0.84 / 1.85$ & $0.84 / 1.85$ & $0.84 / 1.85$ \\
\hline 9. VCHP gas reservoir & $0.80 / 1.76$ & $0.80 / 1.36$ & $0.80 / 1.76$ & $0.80 / 1.36$ & $0.80 / 1.76$ & $0.80 / 1.76$ & $0.80 / 1.76$ & $0.80 / 1.76$ & $0.80 / 1.76$ \\
\hline $\begin{array}{l}\text { 10. Condenser VCHP } \\
\text { and saddles }\end{array}$ & $0.78 / 1.73$ & $1.57 / 3.46$ & $2.35 / 5.18$ & $3.13 / 6.91$ & $3.92 / 8.64$ & $4.70 / 10.37$ & $5.49 / 12.10$ & $/ 13.83$ & $/ 15.56$ \\
\hline 11. VCliP radlator & $0.37 / 1.69$ & $1.54 / 3.46$ & $2.30 / 5.08$ & $3.07 / 6.77$ & $3.84 / 8.47$ & $4.61 / 10.16$ & $5.38 / 11.85$ & & \\
\hline Total & $23,21 / 51,17$ & $24.76 / 54.59$ & $26.31 / 58.01$ & $27.87 / 61.44$ & $29.42 / 64.86$ & $30.97 / 68.28$ & $32.52 / 71.7$ & & \\
\hline
\end{tabular}

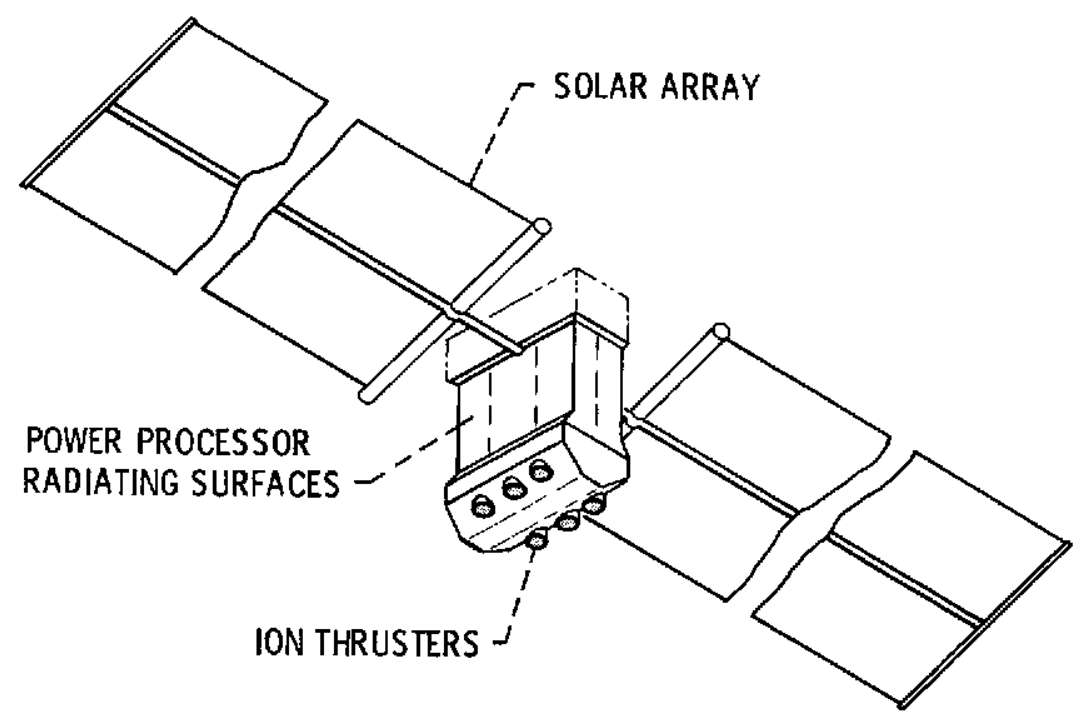

Figure 1. - Electric propulsion spacecraft. 


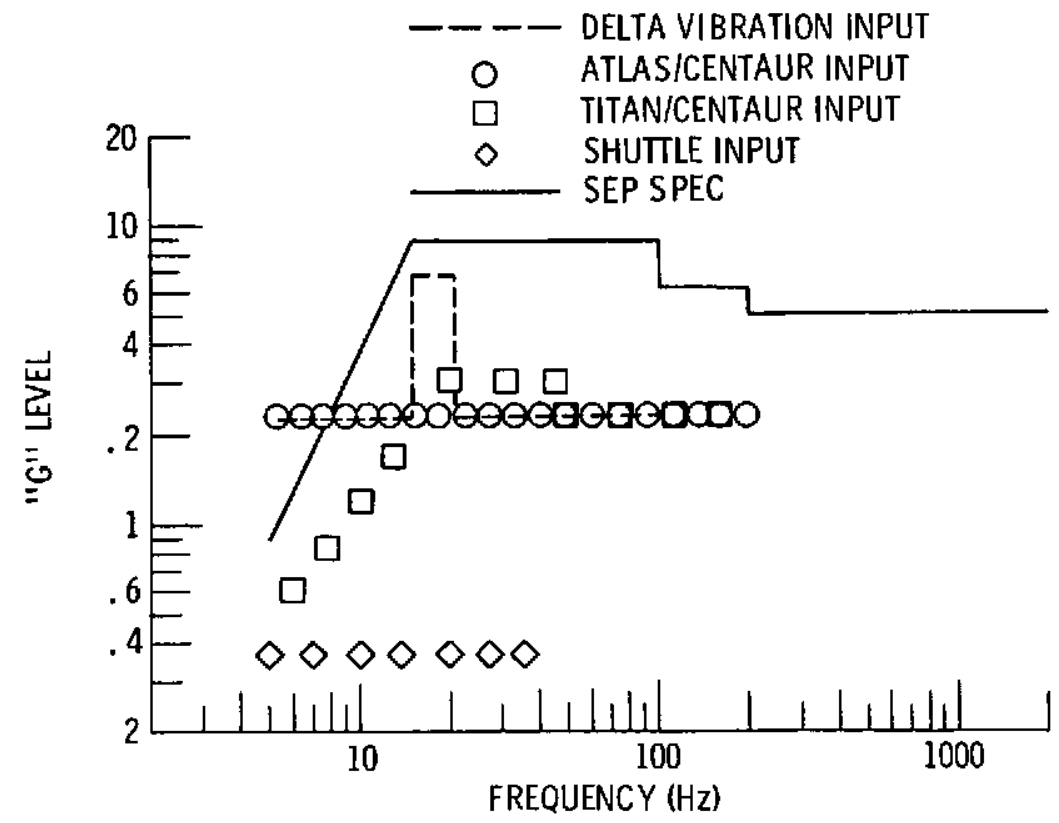

Figure 2. - SEP sine vibration qualification environment.

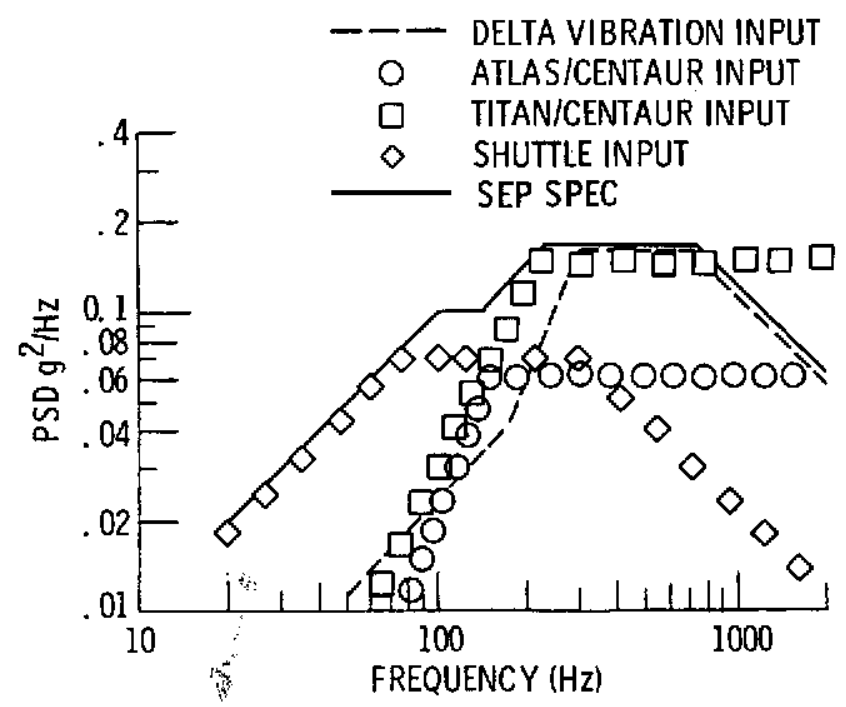

Figure 3. - SEP random vibration qualification environment 


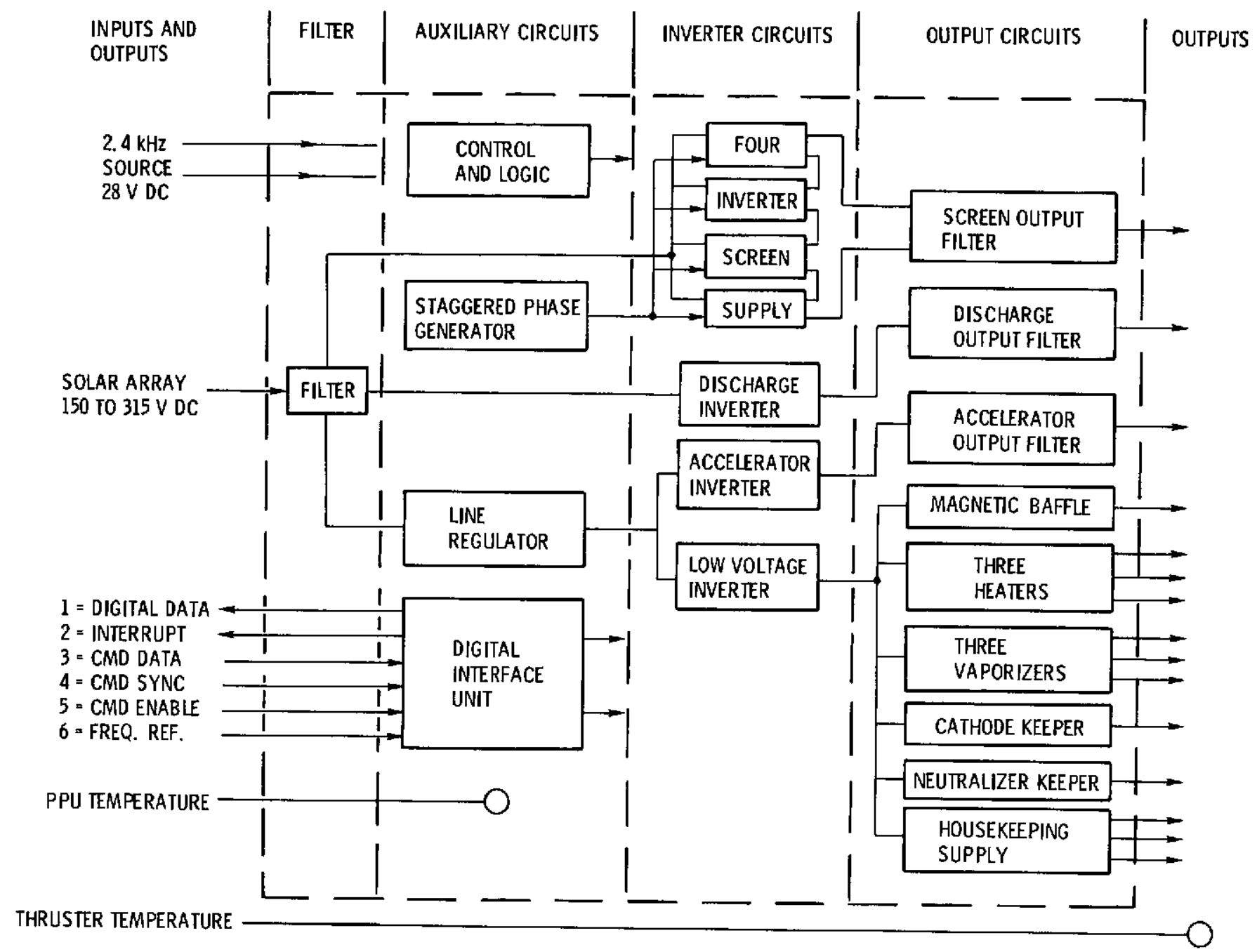

Figure 4. - 30- $\mathrm{cm}$ bridge rectifier transistorized power processor block diagram. 


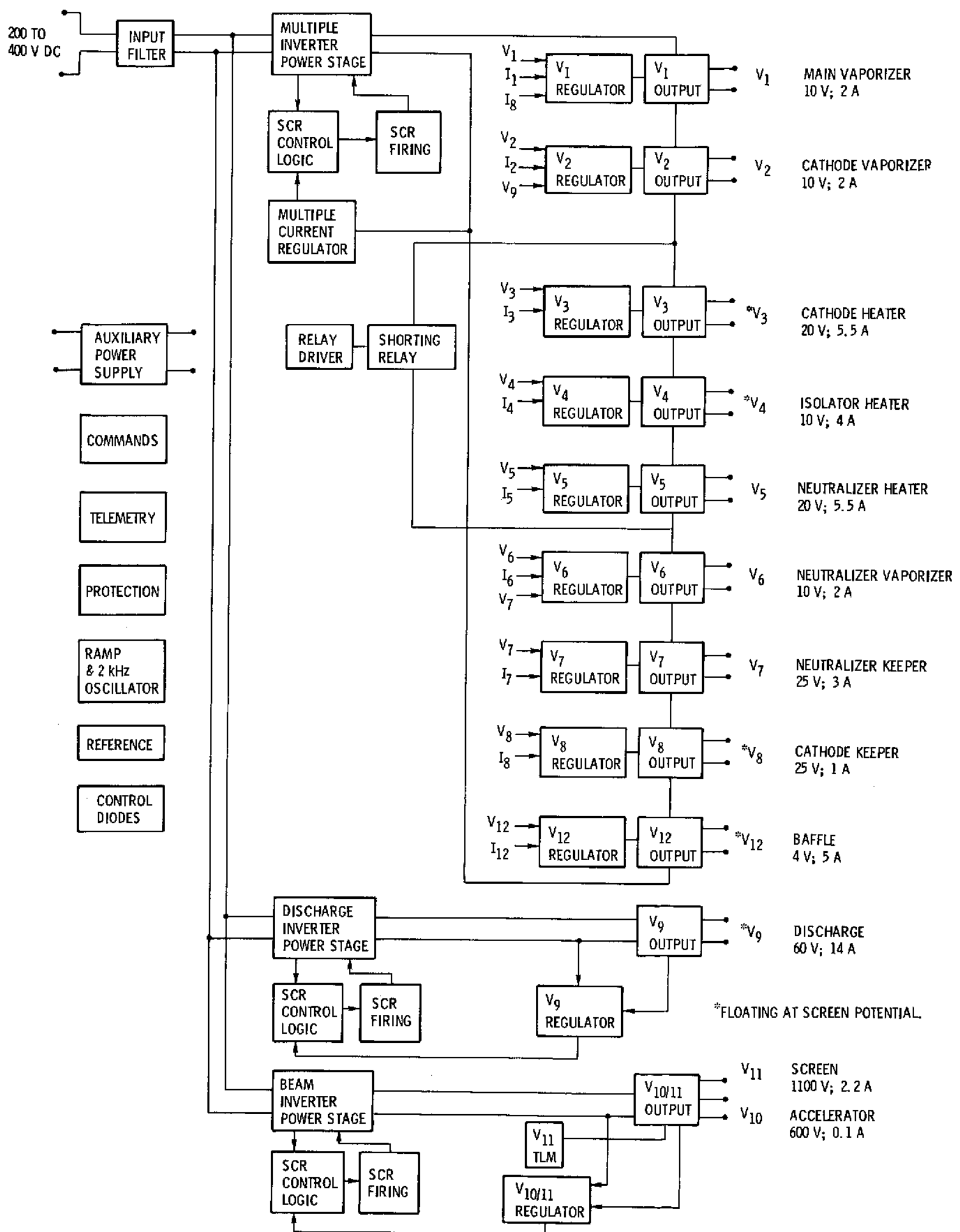

Figure 5. - Block diagram for Series Resonant SCR 3 inverter system. 


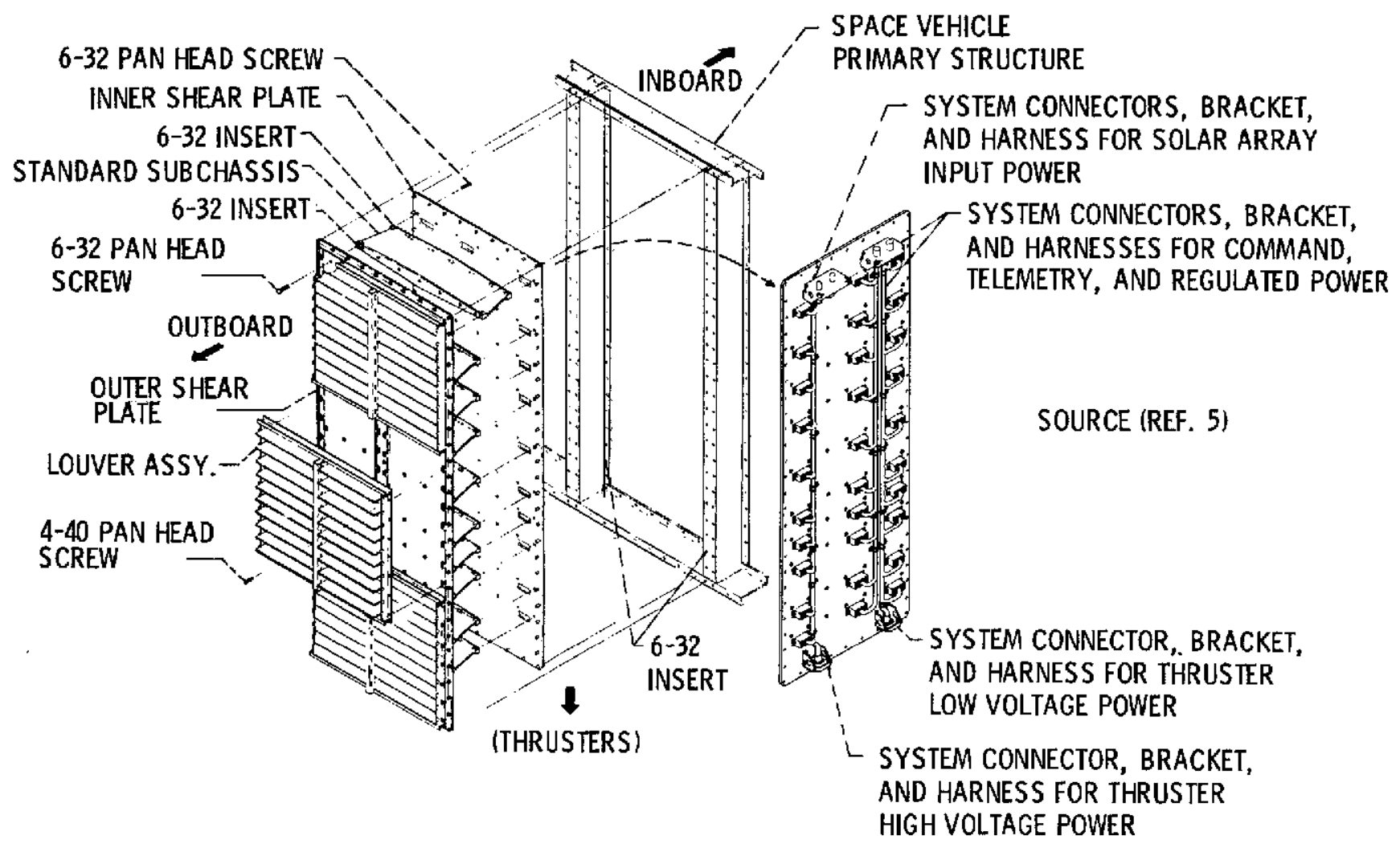

Figure 6. - All louver system with dual shear plate power processor. 


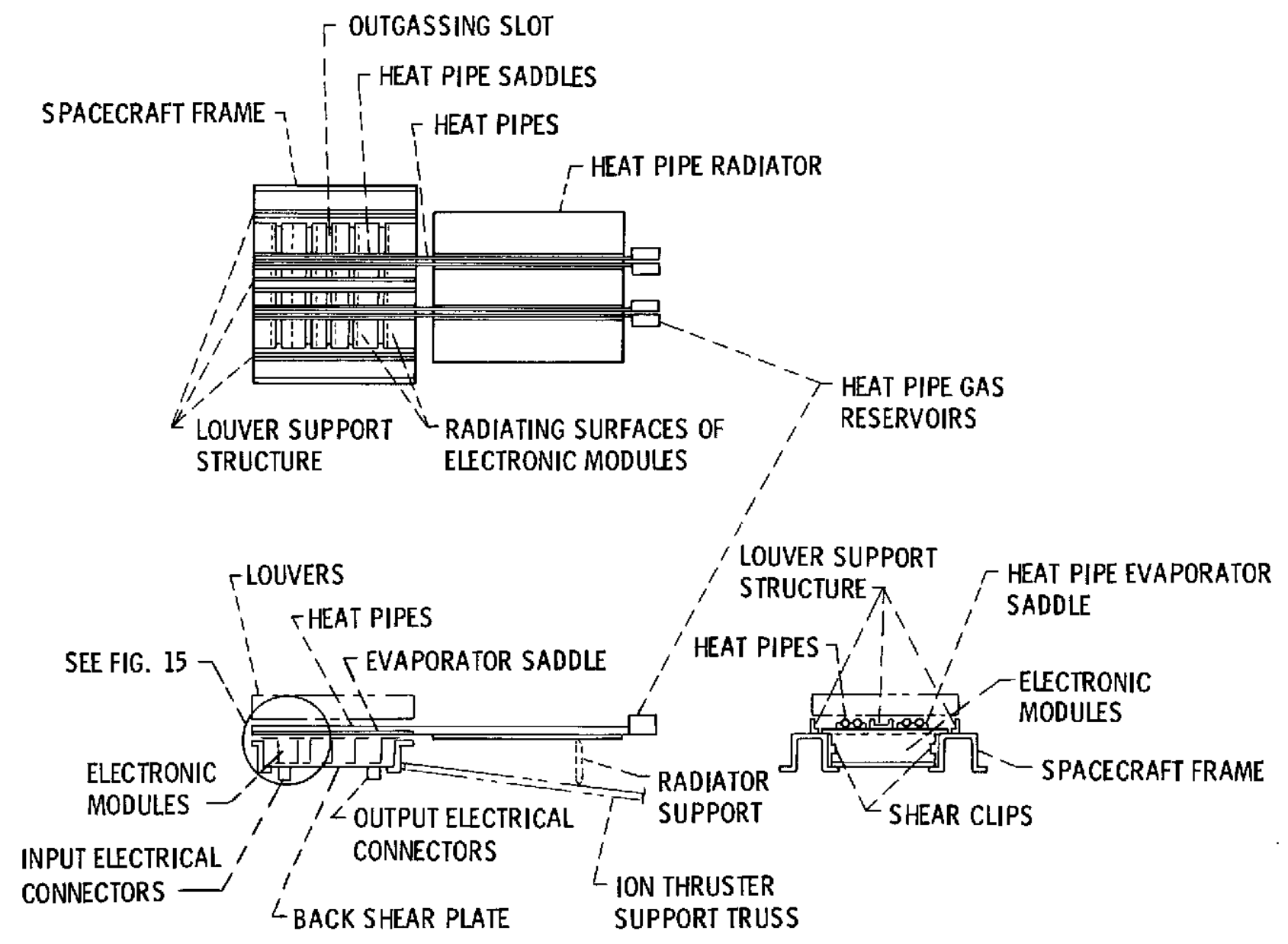

Figure 7. - Variable conductance heat pipe and louver with power processor.

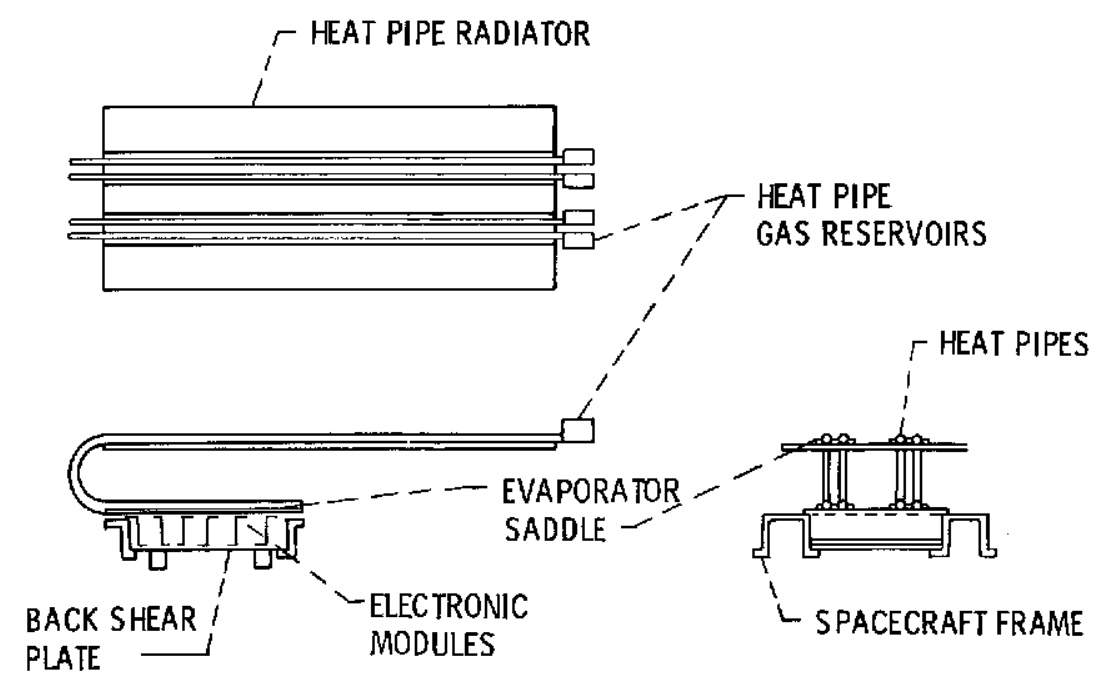

Figure 8. - All VCHPS PPU configuration. 


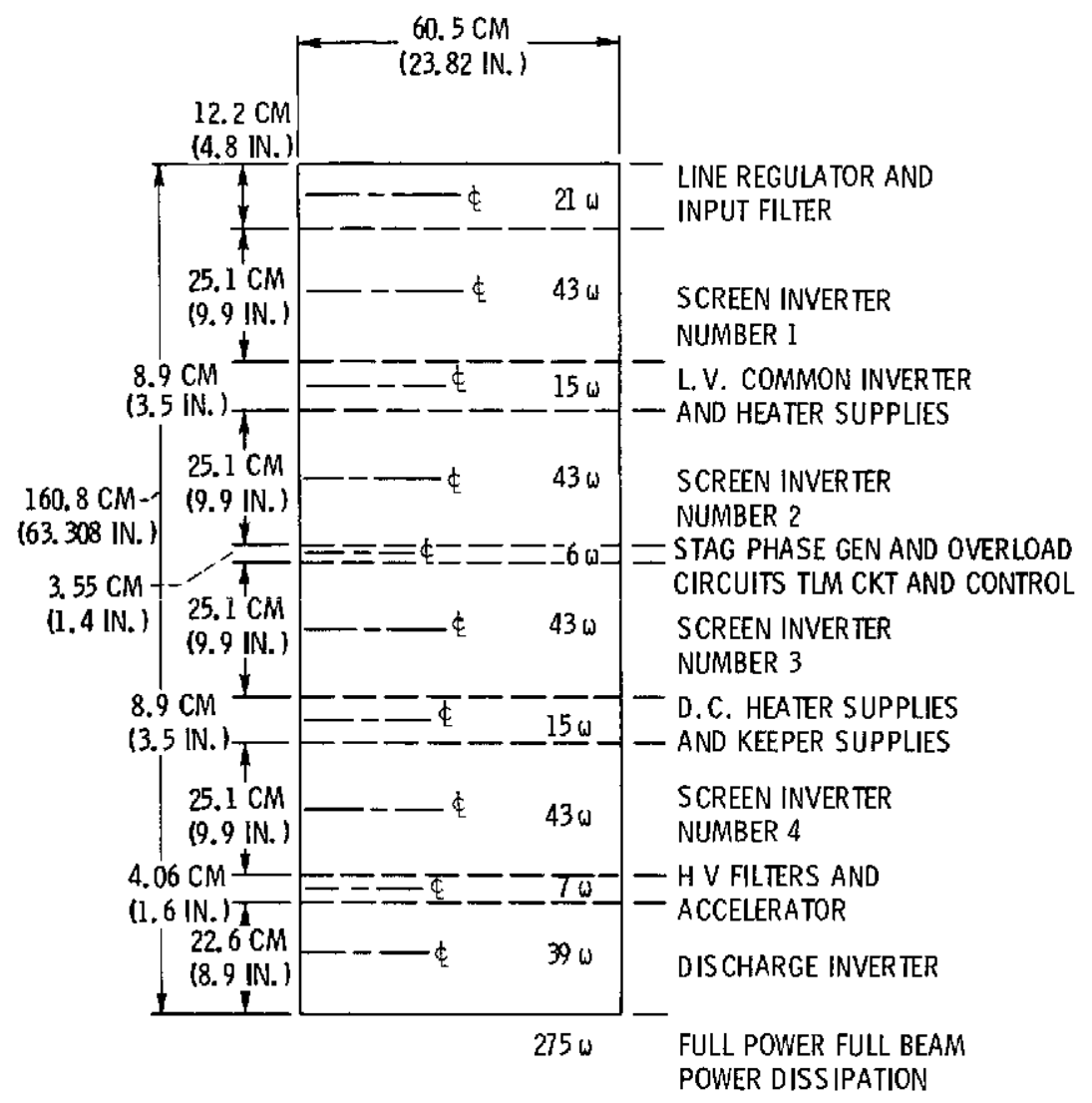

Figure 9. - PPU overall circuit layout for all-lower configurations.

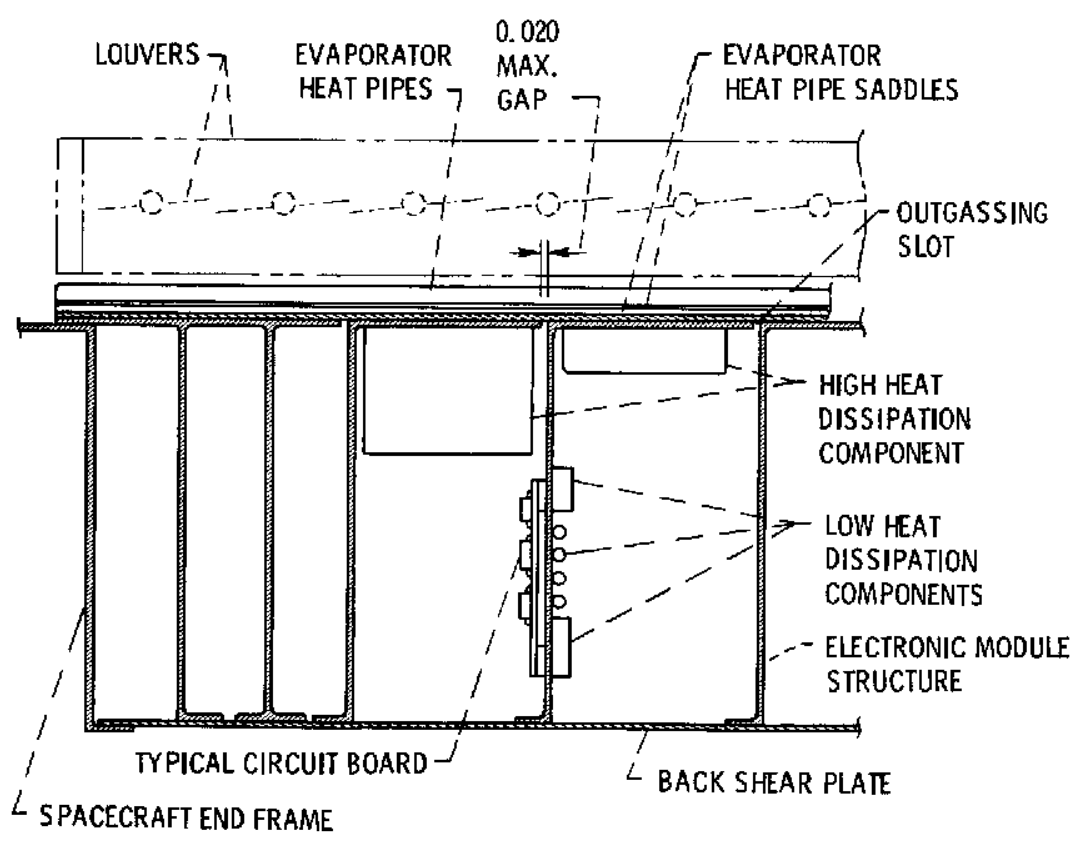

Figure 10. - Typical PPU cross section for modules running widthwise. 


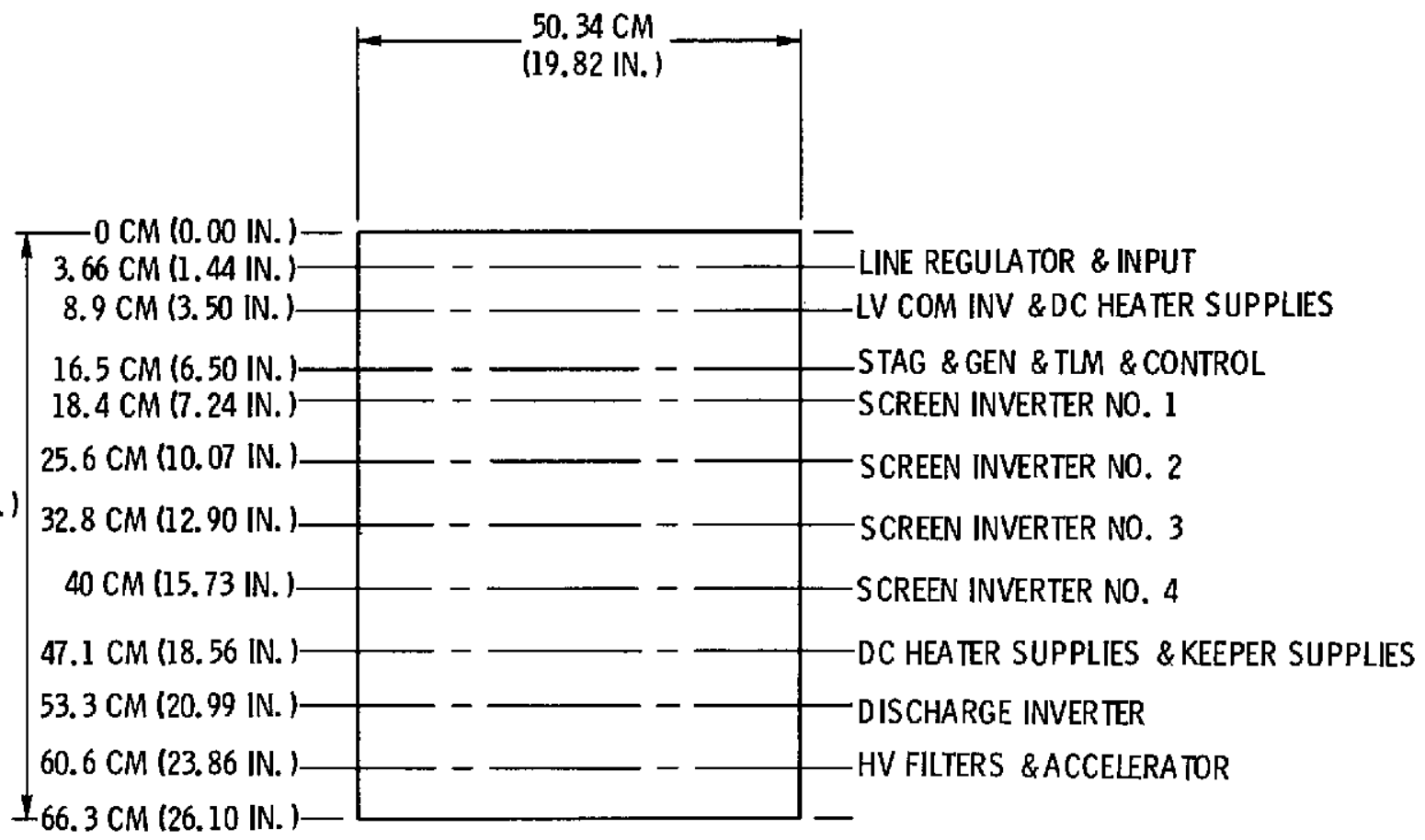

$50.34 \mathrm{CM}$

(19.82 IN.)

(26.10 IN.)

Figure 11. - PPU overall circuit layout for VCHP/louver configuration 
NOTE: DESIGN IS FOR ONE PIPE PER CONDENSER SADDLE TO CARRY

THE HEAT LOAD. SECOND PIPE

ON EACH SADDLE IS REDUNDANT.

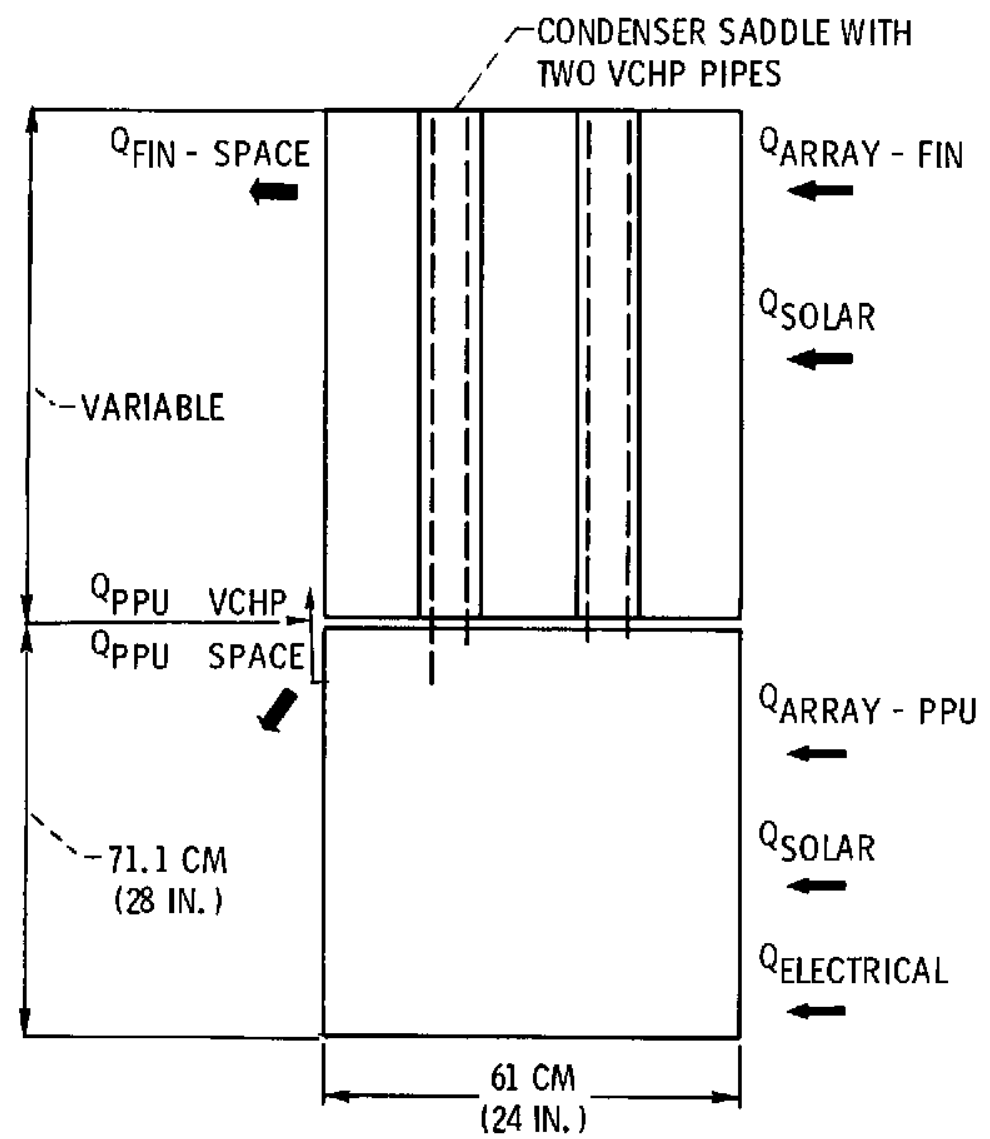

Figure 12. - Major heat paths for typical configuration. 


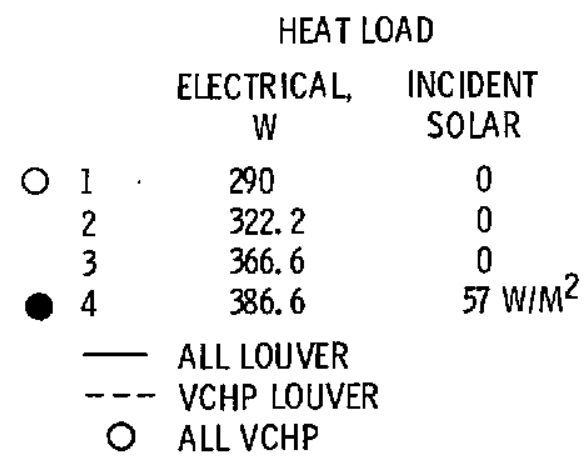

$N$
$\infty$
$\infty$
1
1

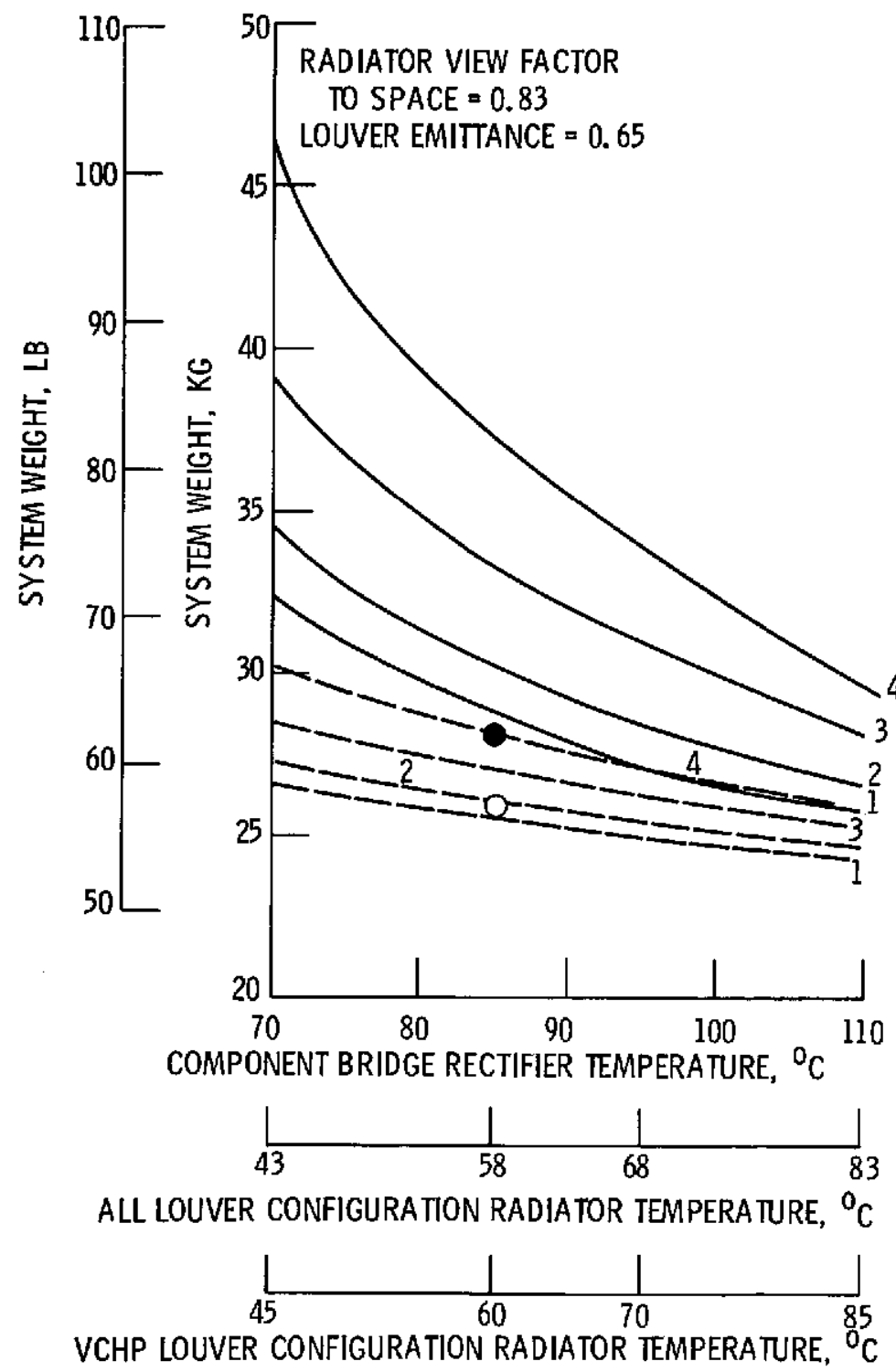

Figure 13. - Comparison of system weights for a solar temperature of $50^{\circ} \mathrm{C}$. 


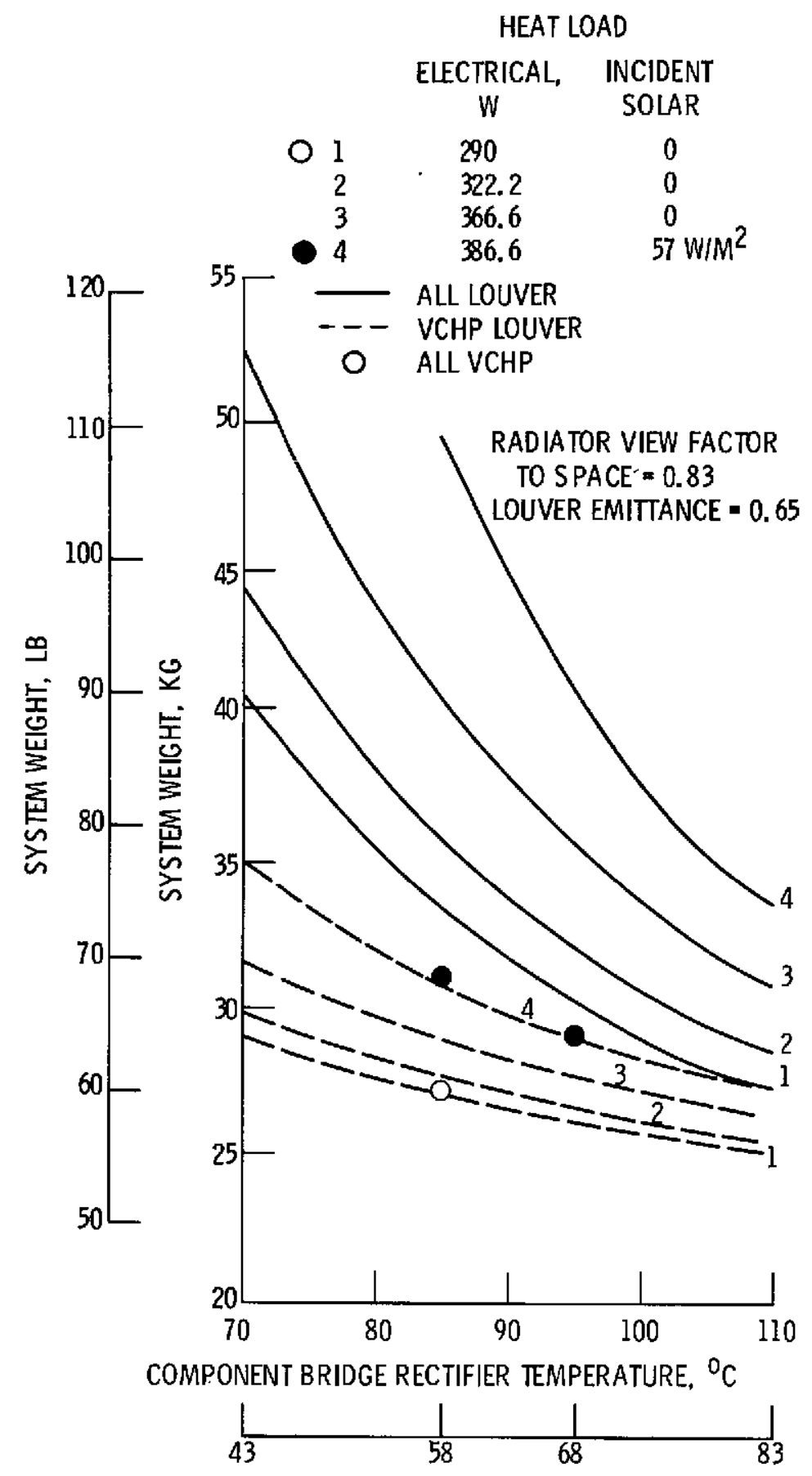

ALL LOUVER CONFIGURATION RADIATOR TEMPERATURE, ${ }^{\circ} \mathrm{C}$

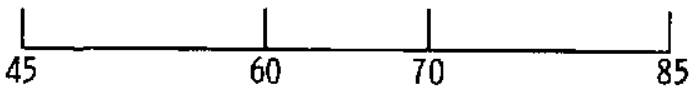

VCHP LOUVER CONFIGURATION RADIATOR TEMPERATURE, ${ }^{\circ} \mathrm{C}$

Figure 14. - Comparison of system weights for a solar array temperature of $140^{\circ} \mathrm{C}$. 


$\begin{array}{ccc} & \begin{array}{c}\text { ELECTRICAL, } \\ \text { W }\end{array} & \begin{array}{c}\text { INCIDENT } \\ \text { SOLAR }\end{array} \\ 1 & 290 & 0 \\ 2 & 322.2 & 0 \\ 3 & 366.6 & 0 \\ 4 & 386.6 & 57 \mathrm{WIM}^{2} \\ & \text { ALL LOUVER } & \\ --- & \text { VCHP LOUVER }\end{array}$

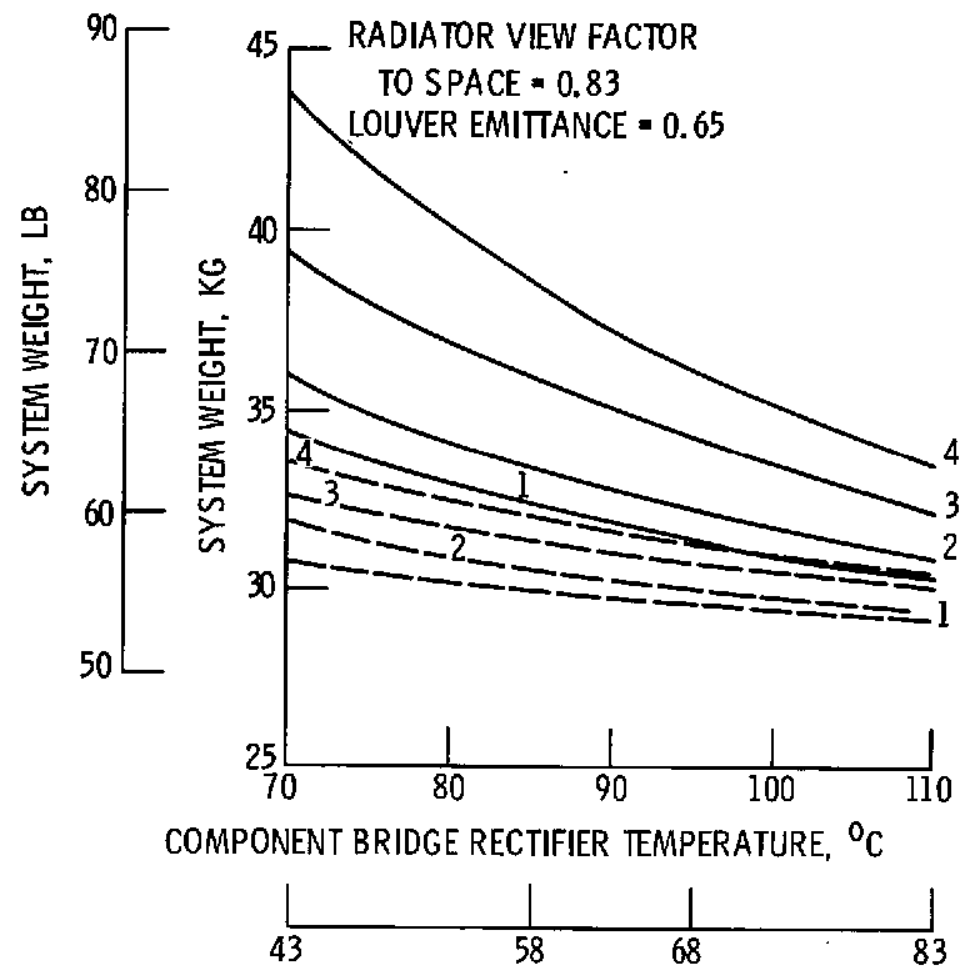

ALL LOUVER CONFIGURATION RADIATOR TEMPERATURE, ${ }^{\circ} \mathrm{C}$

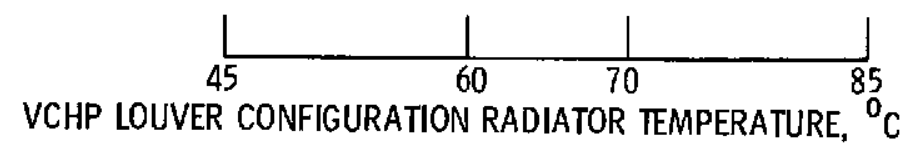

Figure 15. - Comparison of system weights for a solar array temperature of $100^{\circ} \mathrm{C}$. 


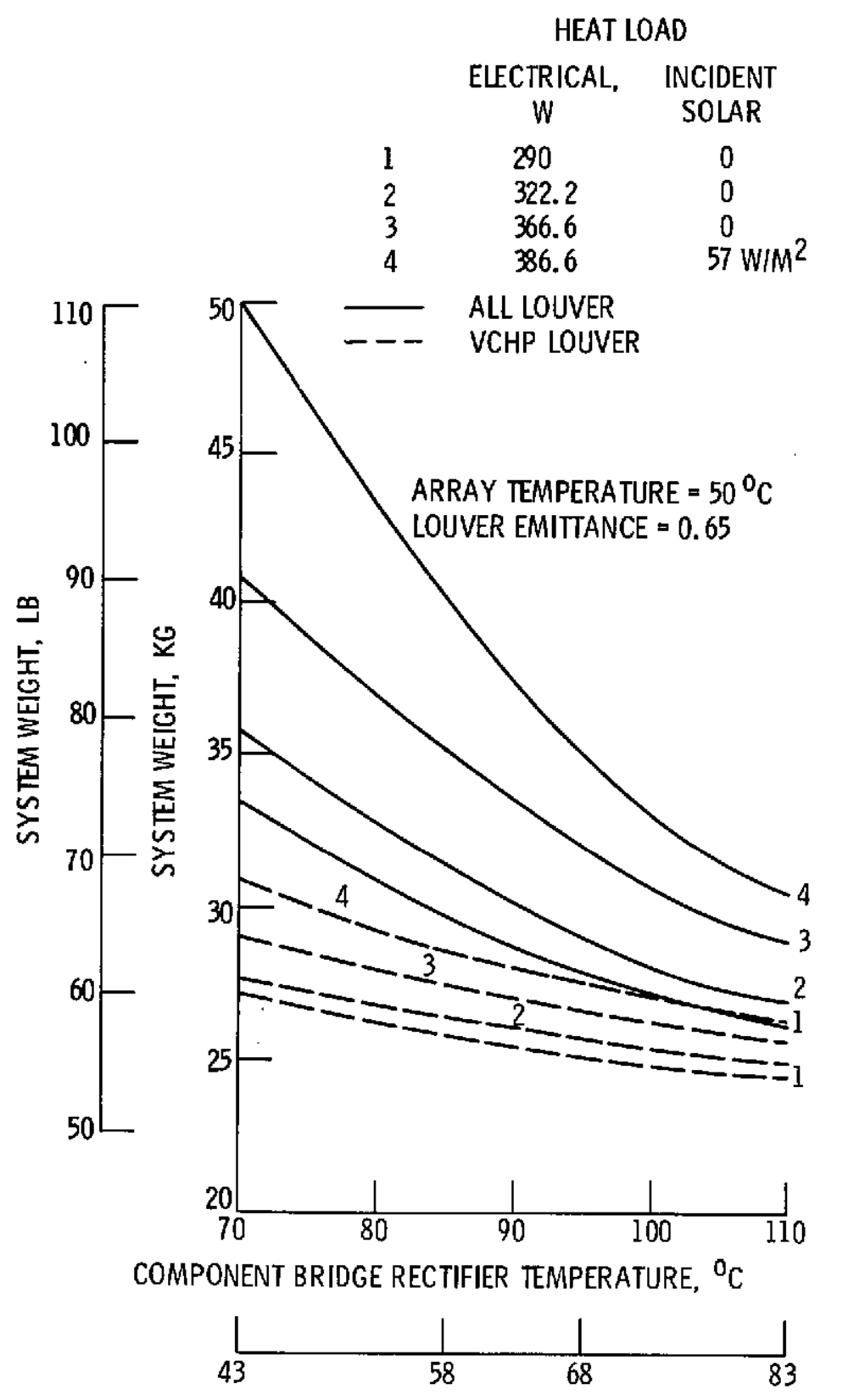

ALL LOUVER CONFIGURATION RADIATOR TEMPERATURE, ${ }^{\circ} \mathrm{C}$

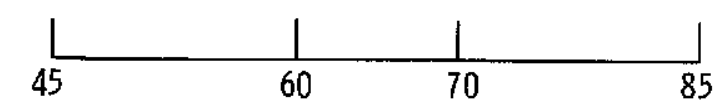

VCHP LOUVER CONFIGURATION RADIATOR TEMPERATURE, ${ }^{\circ} \mathrm{C}$

Figure 16. - Comparison of system weights for a radiator view factor to space of 0.775 . 
ARRAY TEM PERATURE $=50^{\circ} \mathrm{C}$

LOUVER EMITTANCE $=0.65$

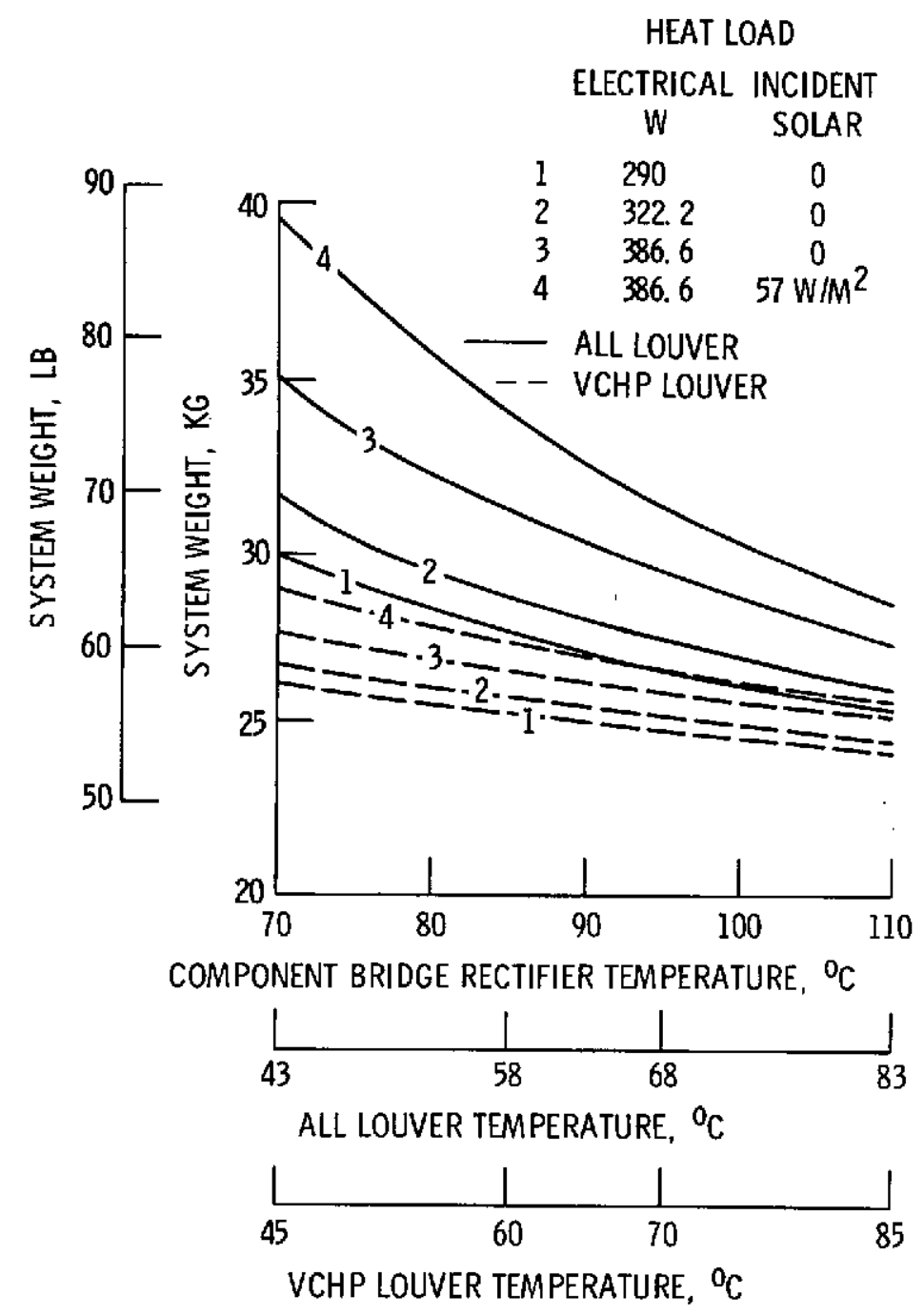

Figure 17. - Comparison of system weights for a radiator view factor to space of 0.94 .
SOLAR ARRAY TEMPERATURE $=50^{\circ} \mathrm{C}$

RADIATOR VIEW FACTOR TO SPACE $=0.83$

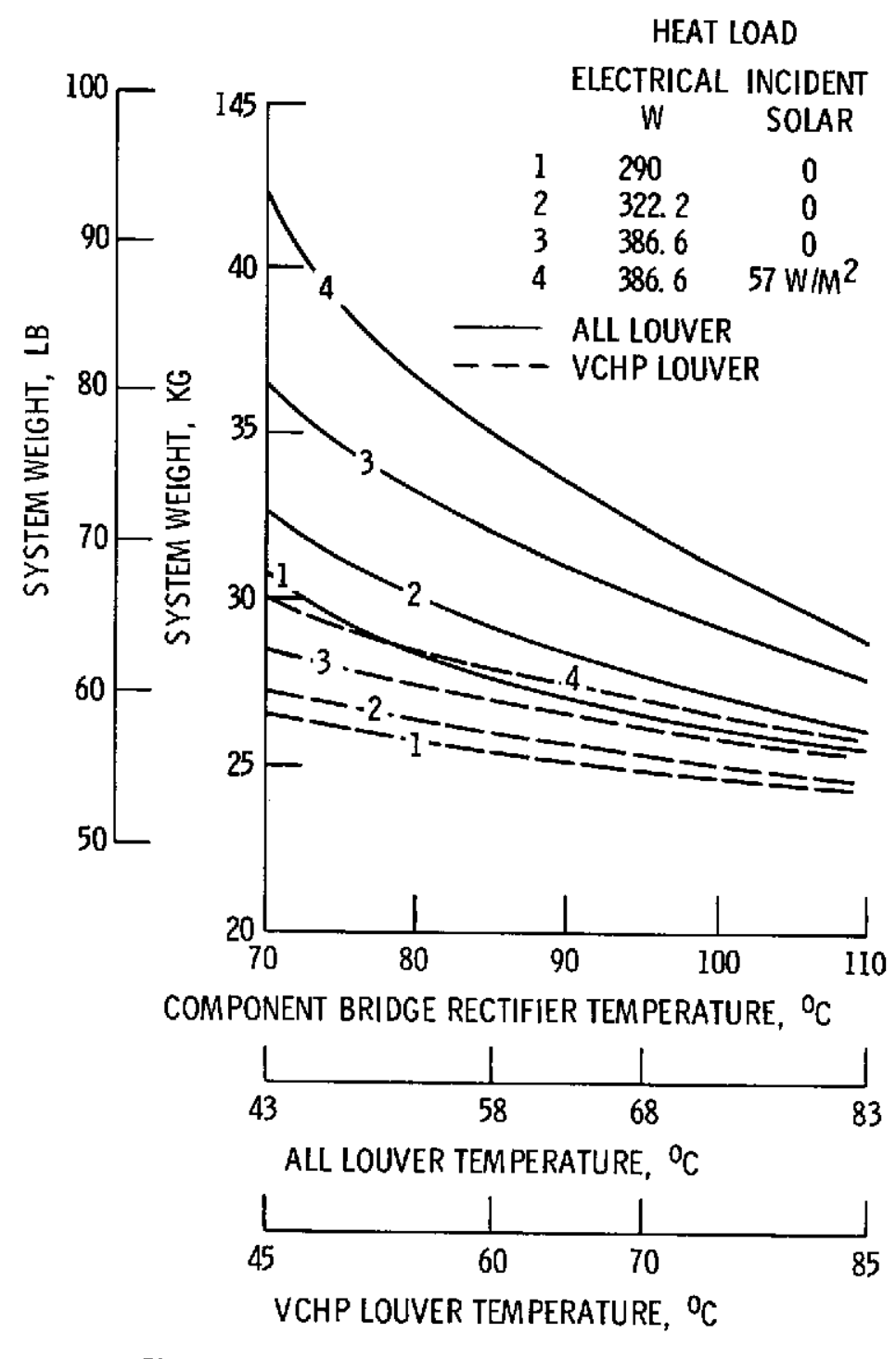

Figure 18. - Comparison of system weights for louver emittance of 0.7 . 

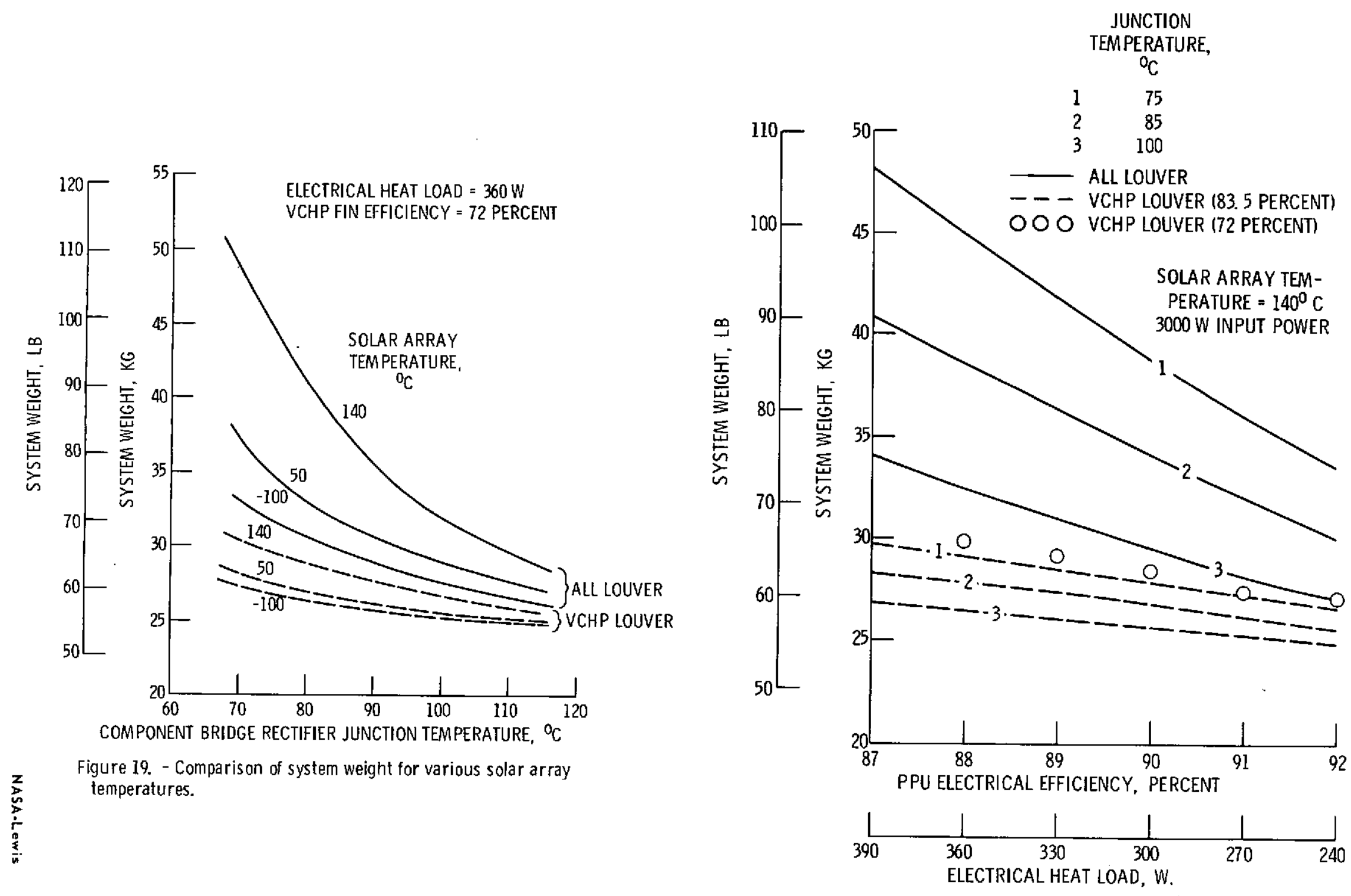

Figure 20. - Comparison of system weights as a function of PPU electrical efficiency. 